\title{
Populism, media and education: challenging discrimination in contemporary digital societies
}

Joanne Yoo

To cite this article: Joanne Yoo (2017): Populism, media and education: challenging discrimination in contemporary digital societies, Studies in Continuing Education, DOI: 10.1080/0158037X.2017.1384630

To link to this article: https://doi.org/10.1080/0158037X.2017.1384630

\section{曲 Published online: 21 Nov 2017.}

Submit your article to this journal $\pi$

山 Article views: 28

View Crossmark data ¿ 
BOOK REVIEW

\section{Populism, media and education: challenging discrimination in contemporary digital societies, by Maria Ranieri, Abingdon, Taylor \& Francis, 2016, 1-206, £110 (hardback), ISBN:978-1-138-92984-5}

Digital tools and mass media has increasingly politicised the education landscape by destabilising traditional power roles and by connecting people on a global scale. In a similar vein, its ability to connect people has enabled it become an equally powerful driver for extremism and narratives of hate. Populism, Media and Education: Challenging discrimination in contemporary digital societies enters into this critical discussion to explore how right wing populist organisations have used digital media to reproduce discriminative activities. It makes a vital connection between rapid societal and technological changes and illustrates how teachers and educators can use digital tools to enable students to become active participants in civic life.

This book is a recent addition to the 'Research in Education' series published by Routledge. It is based on the research project e-EAV (e-Engagement Against Violence), which investigates the effects of radical right discourses and communicative strategies. This project, which was commissioned by the European Commission's DAPHNE programme, incorporates two main methodological approaches. The first includes a Critical Frame Analysis to explore online populist discourses from political groups. The second involves action research to examine existing media and citizenship education initiatives aimed to promote critical civic engagement.

The book provides a critical and analytical account of the key terms included in the title: populism, media and education. It is structured so that readers have a strong theoretical foundation of the challenges posed by populist discourses emerging in European societies. It then draws practical implications relevant to the teaching context. The content is divided into three key sections. The first section describes the literature grounding the main principles of the eEAV project. From this theoretical platform, section two moves onto provide a critical discussion of the communicative strategies of seven EU member states involved in the project. The final section addresses practical implications by looking at ways to enhance citizenship skills through media literacy education. Overall, this book provides a well-rounded perspective by concluding with the possibilities and limitations of engaging students in media activities, as well as teacher perspectives on ways to promote civic engagement in schools.

The primary strength of this book lies in its practical applications to modern day schools. The discussions are drawn from an action research project where students learn to become active learners and citizens via media literacy. Teachers engage in action research to explore ways that discriminatory action in mass media can be recreated as 'teachable moments' through students' media products. The authors also draw our attention to the need for greater teacher training and preparation in how to use media literacy to better equip students to participate meaningfully in the world.

The book provides an excellent foundation of current perspectives on how media frames our life socially, culturally and politically. It is written for a global readership and is highly relevant for educational practitioners and leaders, scholars and policy makers who perceive education as a political act and a cornerstone for a democratic society. It generates important discussions on how creative, emancipatory and innovative uses of digital tools can restore and renew civic life. 
$\Leftrightarrow$ BOOK REVIEW

Joanne Yoo

University of Technology Sydney, Australia

@ Joanne.yoo@uts.edu.au

() 2017 Joanne Yoo

https://doi.org/10.1080/0158037X.2017.1384630

(A) Check for updates 